\author{
Marquette University \\ e-Publications@Marquette
}

Social and Cultural Sciences Faculty Research and Publications

Social and Cultural Sciences, Department of

2020

\title{
The Problem of Humanization: Affect and Investigative Mindset in U.S. Capital Mitigation
}

Jesse Cheng

Marquette University, jesse.cheng@marquette.edu

Follow this and additional works at: https://epublications.marquette.edu/socs_fac

Part of the Social and Behavioral Sciences Commons

\section{Recommended Citation}

Cheng, Jesse, "The Problem of Humanization: Affect and Investigative Mindset in U.S. Capital Mitigation" (2020). Social and Cultural Sciences Faculty Research and Publications. 284.

https://epublications.marquette.edu/socs_fac/284 
Marquette University

e-Publications@Marquette

\title{
Social and Cultural Sciences Faculty Research and Publications/College of Arts and Sciences
}

This paper is NOT THE PUBLISHED VERSION; but the author's final, peer-reviewed manuscript. The published version may be accessed by following the link in the citation below.

Law, Culture and the Humanities, online prior to print (August 8, 2020). DOI. This article is (C) SAGE Publications and permission has been granted for this version to appear in e-Publications@Marquette. SAGE Publications does not grant permission for this article to be further copied/distributed or hosted elsewhere without express permission from SAGE Publications.

\section{The Problem of Humanization: Affect and Investigative Mindset in U.S. Capital Mitigation}

\author{
Jesse Cheng
}

Social and Cultural Sciences, Marquette University, Milwaukee, WI

\begin{abstract}
This article has two goals. First, I demonstrate the challenges that "humanization" poses for the defense as an ideal of sentencing mitigation in U.S. capital trials. Capital case procedure largely neutralizes the sympathetic effects of humanization with jurors. In addition, potential mitigation witnesses inhabit affective environs that undermine any inclination to help the defense through sympathetic testimony. Second, I explain how defense advocacy responds to humanization's challenges. Practitioners adopt an investigative mindset that focuses on forging the conditions to cultivate relationships with mitigation witnesses. This intensive affective labor translates back into the
\end{abstract}


realm of procedure through strategic maneuvers intended to avoid trial and the performance of humanization.

\section{Keywords}

Affect, capital punishment, death penalty, defense, humanization, mitigation

\section{Introduction}

In no other area of U.S. legal practice does the "humanization" of the client comprise such an explicit aspect of advocacy than in capital sentencing mitigation - the process in which defense advocates argue against the imposition of the death penalty for convicted murderers. ${ }^{1}$ And yet, in no other practice area does the high ideal of fostering compassionate, human identification with the client pose such a consistently vexing challenge for the advocate. One reason for this is obvious. The capital jury is confronted with not just homicide but the most aggravated forms of killing recognized by law, often committed by individuals with extensive histories of violence and apparent cruelty. In this article, however, I extend the focus beyond the courtroom and out toward the fields of investigation. There, the work of advocacy is enmeshed with the landscapes of precarity that produced the capital defendant and the members of his intimate community who can best testify about his human qualities. In this wider framework of advocacy, the defense finds itself tasked with a formidable quest. Even as it must prepare to perform humanization to meet the system's expectations of the practice, it must also work through affective realities that are hostile to the cultivation of sympathy at every step of the way, from pretrial investigations of the client's life to formal presentations before sentencers.

The purpose of this analysis is twofold. First, I wish to demonstrate the challenges that humanization poses as an ideal of defense advocacy. Not only is capital case procedure structured to largely neutralize any sympathetic effect humanization might have. There are also barriers in the fields of investigation. The very sorts of suffering that make up mitigating evidence are also experienced by potential sentencing witnesses who knew the defendant and can best testify about his pain. But advocates discover that this shared suffering often puts witnesses in affective states that undermine any sympathetic inclination to help the defense. Second, I attempt to explain how defense advocacy responds to these challenges of humanization. Instead of attempting to elicit sympathetic testimony per se, advocacy adopts an investigative mindset that focuses on forging the conditions to cultivate relationships with suspicious, fearful, and unwilling witnesses. This intensive labor involves deep affective investments - and it also advances advocacy, translating back into the realm of procedure through strategic maneuvers intended to produce outcomes that avoid trial. By framing humanization as a problem instead of an unquestioned ideal, the article seeks to offer a useful analytical window to unpack some of the inner workings of mitigation's time-consuming, human-centered methodology and its implications for defense advocacy.

With explorations of affect being central to these two goals, my approach here draws from affect theory, a humanities-centered body of analysis that traces its lineage back to seminal pieces, published in the same year, by Brian Massumi and Eve Kosofsky Sedgwick. ${ }^{2}$ Within this now-vibrant literature, the notion of affect itself is highly variable and at times quite contested-rightfully so, according to some. ${ }^{3}$ For present purposes, I lean on Ravit Reichman's lucid articulation of affect as "the way that emotional experience consolidates itself out of depths that move us, but that we cannot fully 
acknowledge or apprehend." ${ }^{4}$ Reichman recognizes that emotions, as consciously experienced, figure in a complex of inchoate phenomena and intensities that ultimately move us. ${ }^{5}$ Capital defense advocates, I argue, carefully attend to the affective conditions of advocacy and the ways these shape their own movements in the field. A large part of this labor revolves around the fact that sympathy, the emotional essence of humanization, is roiled, displaced, and often neutralized through the highly charged affective atmospherics of precarity.

During my years as a defense lawyer and field investigator specializing in death penalty cases, I realized the extent to which the project of humanization, ostensibly most relevant to arguments for sentencing mitigation, affects virtually all aspects of capital defense. ${ }^{6}$ The sweeping investigation into any aspect conceivable of the client's existence, together with the development of representational strategies to put this life history evidence to best effect, makes up a significant, even outsized proportion of the practice. Certainly, defense practitioners themselves have had much to say about the requirements of constitutionally acceptable sentencing investigations. ${ }^{7}$ One way to make sense of this is by taking seriously the notion that capital mitigation is imbued with profound affective investments. My interest in mitigation's investigative mindset stems from what it reveals about the emotional undercurrents of precarious investigation. The advocate is well aware of these affective realities and the need to respond to them. But I will show that this methodological self-awareness itself evidences an approach to advocacy that, in key respects, lies sideways to the humanizing project that the law officially demands. This is underscored by the fact that mitigation succeeds in good part through deliberate attempts to put off the performance of humanization at trial in favor of continuing investigation, deepening advocacy's affective investments in the field.

The piece begins by exploring the nuts and bolts of the procedural machinery that gives rise to humanization as a requirement of defense representation. After showing how the formal mechanisms of law predispose capital proceedings against sympathy, I enter the landscapes of precarity. There, potential mitigation witnesses' struggles for mere subsistence take place in an affective atmosphere that reinforces these procedural barriers to humanization. The defense's response, I next argue, is to adopt an investigative mindset that prioritizes advocacy's very survival. This orientation places the practitioner alongside witnesses in affective relationships that are cultivated less for the goal of "representing," sympathetically, the defendant's humanity, and more for the ongoing process of keeping those relationships alive. To conclude, I draw inspiration from Judith Butler's notion of livability to more sharply outline the critical complications that mitigation's investigative practices bring to the ideal of humanization.

\section{The Procedural Framework of Humanization}

For over four decades, the constitutionality of the death penalty in the United States has been grounded on a principle of procedural parity. ${ }^{8}$ Following a verdict of criminal guilt, the same jurors who determine the defendant's culpability sit in a subsequent hearing devoted to sentencing arguments, first from the prosecuting state and then from the defense. Prosecutors who seek the death penalty have the prerogative to cast capital defendants as the worst of the worst offenders. Perhaps their acts of murder stand out as particularly cruel or heinous; or their victims were especially vulnerable; or the defendant's criminal history suggests an incorrigible tendency toward violence. ${ }^{9}$ Counterbalancing this case in "aggravation," defense advocates are procedurally guaranteed the opportunity to delve into 
the biography of their clients' character, record, and criminal circumstances. Capital jurors may deem such contextualizing considerations - evidence in "mitigation" - to outweigh the aggravators, and, consequently, to foreclose execution as the appropriate punishment. Although this moral weighing structure pitting aggravating against mitigating circumstances received the U.S. Supreme Court's formal blessing in 1976, it was a mere four years earlier that the Court had stricken down capital sentencing laws across the land in a controversial and much-publicized ruling. ${ }^{10}$ The death penalty as it had then functioned was unconstitutionally cruel and unusual, too arbitrary in application. Now, the Court was approving the dedicated sentencing phase and its explicit balancing scheme as guarantors of guided discretion in juror deliberations-procedural correctives good enough to restore capital punishment in the United States, where it has remained ever since. ${ }^{11}$

Nevertheless, mere months after executions were reinstated, several of the Supreme Court's members thought it necessary to offer additional instruction on sentencing advocacy for life. The penalty phase defense, they specified, must allow jurors to consider "compassionate or mitigating factors stemming from the diverse frailties of humankind." 12 In this lyrical, even spiritual turn of phrase, defense advocates found heady language for styling themselves as champions of oppressed individuals in the face of a callous sovereign power. Advocates saw a clear mandate to conceive of capital defendants in the most expansive, sympathy-invoking terms possible. ${ }^{13} \mathrm{~A}$ common saying in the work is that a human being is more than their worst act. Compassion, in theory, would situate that act in a lifelong litany of assaults on the defendant's physical person, sense of selfhood, and human dignity. Skillfully done, humanization would empower others to view the capital homicide as but the latest event in a sad history of human beings hurting other human beings. It would enable compassion for both the defendant and the victim-indeed, one because of the other. Over time, as investigations into the client's humanity grew deeper, broader, and more sophisticated-requiring years of trial preparation in some cases - the imperative to "humanize" the client became a core principle of the practice.

In this field of death, however, the project of humanization has long rested on shaky foundations. The quest to convey the humanity in a defendant freshly convicted, beyond any reasonable doubt, of killing, with malice aforethought, is a most daunting one. In the jury selection process, capital jurors undergo a process of "death-qualification" to ensure they are able to impose society's most extreme punishment if the law calls for $\mathrm{it}^{14}$-and now, they have just unanimously declared the defendant guilty of a terrible crime against humankind. Prosecutors who demand blood for blood fully anticipate the defense's humanizing strategies and employ their own maneuvers to inoculate jurors against the draw of sympathetic arguments. ${ }^{15}$ Public sentiment is telling as well. Opposition to the death penalty in the United States is founded less on compassion for killers or on philosophical misgivings about moral payback, and more on suspicion for the legal and bureaucratic machinations involved in a failed government program of state killings. ${ }^{16}$

The promise of procedural parity is also misleading. The defense requires incomparably more investigation, time, and courtroom activities than the prosecuting state. Aggravating factors-for example, the multiple number of victims, the wanton nature of the killing, the crime's commission in the course of another offense-typically have already been suggested or outright established during the trial for guilt. Moreover, the case for death builds on and compounds the fear and anger stoked by the prosecution's proof of the offense. By contrast, mitigation expands drastically outward in time and 
space to encompass the entirety of the client's existence. It must pivot away from technical evidentiary issues that focus on the crime itself to offer a far-ranging, narrative-driven exposition of the defendant's inner world-his lifelong, individualized experiences of those diverse human frailties. ${ }^{17}$ Routinely, and with great vigor, the state contests defense efforts to explore all procedural avenues relevant to the investigation and presentation of a veritable lifetime of evidence; and judges, wary of appearing to indulge in what prosecutors depict as delay tactics, face pressure from victims and the public alike to keep procedural wrangling to a minimum.

Perhaps the most vexing dynamic for the defense is the popular embrace in the United States of a law and order ideology. This establishes the natural position of the sovereign as the guardian of a secure society. ${ }^{18}$ Who should be seen as the embodiment of frailty if not victims and their survivors? If humanization involves the deliberate nurturing of sympathetic identification with others, fear of violent obliteration - of ourselves, of our loved ones-is an effective selling point. The experience of victimization is a universe unto itself, with its own infinite varieties of uncertainty and pain. To speak of the "diversity" of human frailty is, in this light, an incredulous attempt to have homicide victims and their survivors share the same moral umbrella with takers of lives. Furthermore, prosecutors familiar with the humanization playbook know that the defendant's vulnerabilities can be persuasively recast as irreparable damage. His frailties made him want to kill; they will make him continue to kill. Humanity must protect further potential victims from this monster, even if his monstrosity is a product of factors beyond his control. Putting the beast out of its misery, in fact, may be the most humane thing to do.

Finally, received wisdom makes much of the capital defendant's apparent wealth of legal protections. On paper, capital trials require considerably more courtroom activities, long-run advocacy strategy, financial resources, and sheer labor hours compared to other kinds of cases, both civil and criminal. It would seem that the system takes pains to recognize that nothing less than human life is at stake-and yet this belief is belied by a critical truth. Across the fragmented panorama of U.S. criminal justice, the one and only alternative to death by execution, virtually always, is death behind bars: a life sentence without the possibility of parole. Indeed, it is because so very little is on the line-merely these lives, already practically earmarked for caged existence-that the system can afford its procedural largesse. ${ }^{19}$ From the perspective of critique, one might argue that defense advocacy operates with the presumption of human beings always already dehumanized, because always already expelled from the realm of the human. ${ }^{20}$ As one of my colleagues in the practice used to say, "We work so hard because so little and so much is at stake."

Taken together, these systemic dynamics produce formidable headwinds for any practice of advocacy that figures to run on compassion. If humanization is to bear the heavy lifting in the sentencing defense, the practitioner must infiltrate a conceptual space that the executing state has already circumscribed and laid claim to as its own. Capital case procedure has co-opted or choked off virtually all access to sympathetic sentiments that would breathe life into a humanizing paradigm of mitigation. This is not to say that humanization never succeeds on its own terms. But when it does, it is in defiance of stark odds, in a cultural and juridical milieu where its purchase is precious thin. 


\section{Into the Field: The Problem of Sympathy}

When setting forth their thoughts on the "diverse frailties of humankind,"21 the Supreme Court's justices declared that the vulnerability that paved the way for the crime must be explored through the prism of each defendant's individualized experiences. Capital sentencing procedures are to afford "consideration of both the offender and the offense," treating defendants "as uniquely individual human beings, [not] as members of a faceless, undifferentiated mass." 22 According to these jurists, the need to consider the particularities of each capital defendant "reflects simply enlightened policy" in ensuring a "fundamental respect for humanity" ${ }^{23}$ in the sentencing process-nothing less than a constitutional imperative for the penalty of death.

In defense practice, the mandate for sympathetic individualization has translated into a meticulous exploration of the capital client's entire earthly existence-a multigenerational life history investigation feeding into an advocacy practice that, according to one constitutional scholar, is "of an intensity and complexity unknown to any other legal field." ${ }^{24}$ In no small part, this intensity, and the exhaustion that accompanies it, relates to the sheer amount of work to do. The hunt for any institutional record (vital, educational, medical, financial, employment, tax, social services, court, law enforcement, corrections, military, immigration) attached to the client and all family members (his grandmother, his greatgrandmother, his children, their children) aims to leave no stone unturned. Just as wide-reaching are the efforts of human relationship-building with any and all persons who might possibly provide some fragile piece, no matter how apparently insignificant, of the client's life story.

For the zealous defense advocate, the production of knowledge is asymptotic, theoretically without limit. Any nugget of information could be that single finding that persuades that one lone juror to hold out against the unanimous sentencing verdict generally required for death. Long before the trial to determine whether the defendant is even guilty of the offense, the life-minded advocate is already deep in preparations for the sentencing phase, retracing the client's path in the world. These footprints may track near and far: to the home of the defendant's neighbor, where he sought refuge when his alcoholic father beat up his mother; to the grape fields where his dad, without hat, mask, a green card, or a single word of complaint, sat atop a tractor and took in lungful after lungful of chemical pesticides, sprayed in the air like so many gallons of neurotoxic perfume; to the pueblo in the old country where the defendant's grandparents had no running water, but more than enough kin buried by civil war; to the classroom where, years ago, his kindergarten teacher had to disinfect his chair every time he defecated in his pants.

But there are formidable barriers to investigation in the field. These begin with the striking fact that those targeted for the ultimate punishment overwhelmingly hail from wastelands of the social ecosystem. This means that so, too, do those members of his intimate community whom the defense must call to the stand to convey something of the defendant's humanity. To make sense of this challenge, I invoke Ben Anderson's notion of "affective atmospheres" - specifically, his contemplation of "collective affects that. . .envelope' and 'press upon' life." 25 Anderson calls attention to "intensities that are only imperfectly housed in the proper names we give to emotions (hope, fear and so on)." 26 Instead of setting out to cultivate sympathy proper in the arid soil of precarity, I suggest that advocacy proceeds through its encounters with the more agitated affective intensities that surround subsistence. I draw upon the word's etymological meaning of settling at the bottom, like 
sediment, but my focus here is on the falling. Precarity's witnesses, whose willing cooperation the defense so desperately needs, ${ }^{27}$ vie to establish the minimum conditions for a livable life, even as the ground beneath them repeatedly dissolves. The movements of subsistence emerge through its own affective atmosphere; and this is imbued with a complex of emotions that surround the uncertainties of freefall, its recurrent suspensions, and repeatedly dashed hopes of landing on solid footing (could rock bottom get any lower?).

The defense advocate keenly recognizes the ironic dynamic that the very characteristics that are "mitigating" in the law's commanded performance of humanization work to stymie the sentencing investigation. One prominent advocate has described capital defendants thus-

[A]II clients are poor. . .Many have [a] multi-generational history of mental illness. . .Many clients have suicidal histories. . Many have learning disabilities and other cognitive impairments. . Many have organically based neurological deficits. . .Many have physical conditions which affect cognition. . Abuse and trauma histories are virtually universal. . .[Clients] remain hypervigilant in the expectation that random violence may visit them again at any moment. . .Polysubstance abuse and addiction are commonplace. . .Many clients are descendants of slaves. . Many clients have experienced abandonment. . .

- before dryly noting, "Clients are difficult to interview about their own lives." ${ }^{28}$ Writing about the defendant's family environment, advocates have similarly emphasized that

[f]amily members may also share the client's cognitive or psychiatric impairments. They may abuse alcohol or other substances. There may be practiced denial of traumatic events and learned silence as to the norms of society for relatives who have been mis-socialized and corrupted as they grew up. Even absent trauma and corruption, family witnesses are often simply poor historians, flawed by their perception and insight, selective memory, biases, and inability to articulate. Finally, they have "normalized" whatever their life experience was. They do not automatically identify the signs of trauma, abject poverty or neglect that were everyday occurrences in their particular social group. ${ }^{29}$

And finally, one investigator speaks of all potential social history witnesses in observing, "In most cases lay witnesses are initially suspicious of people asking questions about the client because, like the client, their experiences have been with individuals wanting to hurt them." 30

As subsistence's withering exposures carry on their destruction of brains, bodies, and souls, the capital defender enters the client's world understanding that the felt intensities of precarious life rise up through the fractures of this brokenness. In the affective atmosphere of the field, the intensities that immediately "press upon" the advocate typically coalesce in some erratic combination of paranoia, fear, normalization, denial, skepticism, anger, hostility, and self-serving opportunism. For many individuals who know something of the client's pain, the prospect of self-incrimination through any involvement in legal processes often proves terrifying. Themselves the bearers of intergenerational psychological and physical damage, precarity's "witnesses" often have limited awareness of the effects of their disadvantage on themselves and the defendant. Those who have little sympathy for the client-“I grew up even poorer and even more abused and I didn't become a murderer"-may be desperate for even the smallest sense of self-efficacy in seemingly intolerable life conditions. For 
society's most deprived, neoliberal ideology eagerly furnishes that illusion of agency: Success will be achieved by summoning the intestinal fortitude to pull oneself up by the bootstraps, to find the resourcefulness to do more with less, to welcome adversity and austerity with a can-do spirit. ${ }^{31}$

Against the backdrop of precarity, the call to nurture compassionate appreciation of the defendant's frailties, even among those who would presumably identify with those vulnerabilities and tell about them best, is a tall order. Certainly, the advocate espies frailty and the fact of its diversity. But they also see that the violence engendered by the client's experience of vulnerability is not always extraordinary. They see that on precarity's unforgiving terrain, frailty is everywhere, and that, with due respect to the high court's liberal justices, it is unremarkable especially to those held captive by it, no matter how unique its expression in different lives. They see that out there in the field, where the notion of frailtyas-vulnerability has become banal in precarity's lives and landscapes, the responses of individualized understanding and mercy that are to be activated through sympathy are short-circuited from the start. They see that when everyone suffers through their own varieties of vulnerability, many simply are not persuaded of the need to contemplate what makes this defendant's so special. The advocate, of course, never dismisses the possibility that humanization's sensibilities might yet carry sway with any witness in any given interaction. They just do not count on it.

As an advocacy project, humanization emphasizes human susceptibility to suffering-the fact that strengths can always be undone by vulnerabilities - along with human beings' status as bearers of a sense of mercy that greater powers have already shown all of us. ${ }^{32}$ If to err is human, then to render error intelligible is to humanize. And so humanization, tinged as it is by the gospel of compassion, focuses on the recruitment of potential sympathizers (jurors, prosecutors, judges, witnesses, the victim's survivors). The act of capital violence is depicted as the collapse of an existence cobbled together with crude, makeshift supports that were always destined to fail. This collapse can be made intelligible ("mitigated") by telling the story of an individual-specific genealogy of pain that begins even before the embryonic state of this human being. The good advocate conveys some of the experiences of intergenerational vulnerability spun out in the fabric of the defendant's reality. The great advocate weaves into this already complex tapestry the client's stumbling efforts of hope and even heroism in defiance of his impairments and overwhelming odds. And the outstanding advocate is able to lift this cloth off the loom entirely, laying bare the technologies of violence that structured suffering and explosive expressions of pain into the very warp and weft of the defendant's lifeworld.

It is now a de facto requirement of capital defense practice that sympathetic humanization be formally enacted should the case go to sentencing. An influential capital case management manual for judgesthe official showrunners of evidentiary admissibility-reveals the perception from the bench that mitigation hearings are "extremely emotional" affairs in which one can expect to see "tears. . flowing" from jurors. ${ }^{33}$ But the affects that envelope and press upon subsistence life necessarily envelope and press upon the practice of advocacy. Whereas humanization would cast the advocate as a bold emissary of humankind's better angels, steadily winning converts, courtroom witnesses, and sympathetic jurors in a grassroots campaign culminating in a verdict for life, subsistence has the advocate gingerly stepping into precarious worlds, encountering charged affective environs with their own atmospherics - swirls and eddies that flare up or recede, unpredictably, in expressions of rejection, disassociation, deference, or aggression. Whereas sympathy would somehow forge long- 
term, self-sacrificing commitments from the oppressed in the name of justice, subsistence fractures communities through epigenetic assaults that predispose individuals merely to hang on, by fight or by flight, for just another day. Capital defenders, then, must strategize their movements carefully if advocacy itself is to survive.

\section{The Subsistence Mindset: From Investigation Back to the Courtroom}

I have been arguing that, in fact, advocates are in survival mode twice over: first within the procedural apparatus of capital sentencing law, and second in the investigative environs of precarity. In response to this dual problem, I now suggest that the defense develops a particular investigative mindset-one that converts the needs of human relationship-building into courtroom arguments to prolong investigation. The thumbnail summary of life-minded sentencing advocacy is that time favors the defense-and the multigenerational investigation into the client's life is nothing if not time-consuming. Prosecutor's offices are more likely to "deauthorize" capital proceedings (in favor of routine, noncapital charges) when months and even years of trial preparation have made the horrors of a case fade in public memory. A negotiated disposition for any sentence less than death, is, in fact, the default goal of effective defense advocates. ${ }^{34}$ Mitigation consumes time not only because the defense continuously advocates for hours and resources to conduct a constitutionally "adequate" sentencing investigation. ${ }^{35}$ In addition, the mitigation investigation directly informs and supports a series of pretrial challenges that can pave the way for plea negotiations. ${ }^{36}$ In affective terms, these maneuvers might be depicted as expressions of the way affects "pick up density and texture as they move through bodies, dreams, dramas, and social worldings of all kinds"37_crystallized moments of procedural activity that originate from deep within advocacy's movements through precarious life. In strategic terms, these maneuvers might be viewed as a subversion of a process in which humanization is supposed to be enacted at trial.

Under this approach to advocacy, the investigative mindset is geared toward the need to keep human relationships alive. As much as the practitioner remains mindful of the formal endgame (to produce sympathy-inducing testimony), they set foot on precarity's cracked pavement seeking, first and foremost, to foster social relationships, every moment of which figures to be hard-won. Thus, one academic-practitioner suggests that the top interview goal of mitigation investigations is the need to "build rapport \& trust," as supported by a secondary goal, to "enable release of feelings." 38 This demands that the practitioner "concentrate on emotional messages" 39: "Follow emotional cuesprevent shut-downs-but do not push-respect boundaries." 40 The directive to "note interviewee's appearance, behavior (e.g., facial expression, eye contact, attentiveness, compulsions), affect, relation to the interviewer (cooperative, hostile, seductive, indifferent), thinking (orientation to time \& place, confusion, drowsiness), insight, memory, speech" reflects a certain investigative priority. The emphasis lies not on what facts this witness has to divulge just yet, but on what might be learned about this person and their situation in attempting to co-construct the conditions for further engagement. ${ }^{41}$

Accompanying this tilt toward relations over testimony is a certain fastidiousness in how the defense collects information relevant to the relationship-building process. The advocate keeps careful archives of all records and public searches they have compiled about precarity's witnesses before approaching them in person. ${ }^{42}$ For the practitioner, it is of great affective importance if court filings reveal that a witness has recently been released from jail, or that a restraining order has just been filed against 
them, or that an enforcement order is now in effect for delinquent child support. As an ethnographically trained lawyer, I was also struck by the defense's own forms of records-keeping as artifacts of knowledge production. On defense teams I worked on, the contents of each witness interview were summarized in a "fact" report, each of which had a corresponding "impressions" memorandum placed under separate file. The latter typically addressed issues like the advocate's strategic concerns for further relationship-building, emotional impressions, observations of interactions with others in the interview setting, and potential impacts of the interview on outreach efforts with other witnesses and the client. Unlike the fact reports, which were subject to discovery by the prosecution, we wrote these impressions memos all in italics, literally inscribing their incognito status as protected attorney work product. And yet, despite their literal nonexistence in public adversarial proceedings, these notes often were significantly longer (sometimes several times over), more involved (in the common scenario where witnesses refused to reveal much), and followed with greater interest (particularly in initial interviews) than their "factual" counterparts-a testament to the ongoing need to achieve baseline levels of rapport with each witness, on their own unique terms. ${ }^{43}$

The observation that the mitigation investigation is "a sensitive, complex, and cyclical process" 44 speaks to the fundamental concern that shapes the investigative mindset: What will keep the investigation into the client's life moving? How to create the conditions so that precarity's witnesses will unlock their doors and keep them open for yet another day? In these questions, mitigation's methodology reflects a subsistence mentality that places the capital defender alongside precarity's witnesses in a field of scarcity and conflict. Anticipating the fraught affective atmospherics of precarity, this approach is oriented toward the struggle for advocacy's very survival as the practitioner hustles to eke out even the smallest toehold for dialogue with individuals who are stressed, anxious, depressed, defiant, self-destructive, fearful, and always falling. It plunges advocacy into the depths from which these emotional experiences arise, compelling the advocate to muddle through them with slow, painstaking practices of attunement. From a critical point of view, the forces that stack the procedural deck against the capital defendant are bound up with those forces that produce entrenched precarity. These, in turn, are bound up with forces that now expect that the advocate somehow extract sympathy from the same precarious landscapes that produced the capital defendant in the first place. In the face of these challenges, successes are measured in small increments. ${ }^{45}$

Certainly, the advocate never ceases to assess in what ways sympathetic humanization carries sway with any particular witness at any particular time. A Judeo-Christian inspired ethos of care might yet work to instill sympathy for the oppressed (even as religiously inspired dogmatism might justify oppression). Some individuals might appreciate seeing the client explicitly humanized with vulnerable qualities (even as they themselves might resent being treated as a charity case). One witness may be attracted to the performance of humanization for its illusion of self-agency; they enjoy the fiction of inhabiting stable higher ground from which to pull up others less fortunate. Another witness may approach the defendant's humanization as a diversion from a suppressed inner life, or an indulgence in the fantasy of an unprecarious existence in which compassion actually matters. And finally, should the issue of sentencing need to go before a jury, it has undoubtedly been my experience that the defense will attempt to enlist precarity's witnesses to perform humanization to the hilt in the theater of the courtroom. 
Nonetheless, the affective investments of capital defense practice begin in and always angle back to precarious life in vivo, where advocacy continuously strives to deepen the depths that can be known of each witness's emotional experience. For all the discussion of heightened safeguards in capital trials, it is telling that one repeated effect of these procedures (many of which had to be won through litigation appealed all the way to the highest court of the land) is to redirect advocacy back to the affective labor of investigation. ${ }^{46} \mathrm{It}$ lies beyond the scope of this article to offer a doctrinal analysis of the roots and trajectory of these cases. I would point out, however, that even as procedural challenges present themselves as the formal manifestations of deeper affective investigations, they are far less frequent than the quieter, more micro-level movements that fuse advocacy with the bodies, dreams, dramas, and social worldings of precarious life. These include the delivery of greetings from a childhood friend to the client, the hug that the advocate receives from the client's aunt who watches his young son while the advocate speaks to the mother, and the motion for a hot meal for the defendant. ${ }^{47}$ And all the while time ticks on. Investigation does more than simply provide the evidentiary basis for legal argument. In their attunement to affect, capital defenders have approached precarious relationshipbuilding as a fundamental activity of advocacy whose face-to-face encounters are always transforming the full scope of the practice from the ground up.

\section{Conclusion: On "Humanability"}

Contemplating power structures that expose certain human beings to annihilation, Judith Butler has sought to lay the intellectual foundation for "a more livable set of economic, social, and political conditions no longer afflicted by induced forms of precarity." 48 Livability calls for moral inquiry into the context and content of acceptable existence: "When we ask what makes a life livable, we are asking about certain normative conditions that must be fulfilled for life to become life." 49 Analogously, I ask here what the normative conditions might be for a human being to be recognized as human. What makes a human being "humanable"? Without using the term, Butler grapples with this concern, too ("Which humans count as the human? Which humans are eligible for recognition. . ?" 50 ), mindful of how the question is inextricably tied up with analytical efforts to make sense of a livable life.

As something of a critical counterpoint to humanization, the notion of humanability I present here captures aspects of capital mitigation practice that productively complicate its stated ideal. Humanization predefines the human in "compassionate" qualities that activate sympathy. Humanability, by contrast, holds out the human as a more open object of investigation, approachable through an incremental process of cultivating the individualized normative conditions necessary for inquiry with each one of precarity's witnesses. Humanization emphasizes frailty as an empirically accessible characteristic to be displayed in all its diversity. Humanability engages with vulnerability as a condition of advocacy, focusing on the more sober assessment of what, really, are the dynamics of mutual influence between the advocate and the human beings on whom advocacy must rely. And whereas humanization comes laden with ethical pre-scriptions, looking to write/represent what has been designated in advance as good and worthy of mercy, humanability is a practice of re-cognitionlearning again - that arises from the grind of process work on precarity's shifting ground, where bodies are always falling and the advocate never stops revisiting the relationships that make inquiry possible.

Sympathy holds that to err is human. For the subsistence-minded practitioner, however, Butler's "induced forms of precarity" make error inevitable precisely for the purpose of being able to punish it. 
In this article, I have proposed that the investigative mindset of capital mitigation is rooted in a selfawareness of its own precarious positions, both in the fields of investigation and in the procedural framework of law. Induced precarity has both produced the error of the capital crime (punishable with some form of death within confinement) and promoted the error of investigation's failure to elicit sympathy (punishable with the client's death by execution). While humanization attempts to make error intelligible, humanability obsesses over even the smallest of possibilities within conditions systematically structured for error to be reproduced. The capital defense advocate embraces this critical complication of mitigation's stated ideal as the truer reflection of the practice's affective realities, from people to process.

\section{Footnotes}

1. "[T] he threshold task facing a lawyer in a death penalty case is to make the client a human being, i.e., to humanize him." Dennis Balske, "The Penalty Phase Trial: A Practical Guide," The Champion (Mar 1984), 40-6, p.41. "[C]ounsel must be able to humanize the defendant." American Bar Association, "Guidelines for the Appointment and Performance of Defense Counsel in Death Penalty Cases," Hofstra Law Review 31 (2003), 913-1090, p. 1009. "The goal is to humanize and contextualize, but not to normalize, the client." A Practitioner's Guide to Defending Capital Clients Who Have Mental Disorders and Impairments (Anne James and Matthew Cross, eds) (Woodbridge, VA: International Justice Project, 2006), p. 21.

2. See Brian Massumi, "The Autonomy of Affect," Cultural Critique 31 (1995), 83-109; Eve Kosofsky Sedgwick and Adam Frank, "Shame in the Cybernetic Fold: Reading Silvan Tomkins," in Shame and Its Sisters: A Silvan Tomkins Reader (Eve Kosofsky Sedgwick and Adam Frank, eds) (Durham, NC: Duke University Press, 1995), 1-28.

3. An influential introduction to the field notes the proliferation of "theories as diverse and singularly delineated as their own highly particular encounters with bodies, affects, worlds." Gregory J. Seigworth and Melissa Gregg, "An Inventory of Shimmers," in The Affect Theory Reader (Gregory J. Seigworth and Melissa Gregg, eds) (Durham, NC: Duke University Press, 2010), 1-25, p. 4.

4. Ravit Reichman, "Law's Affective Thickets," in New Directions in Law and Literature (Elizabeth S. Anker and Bernadette Meyler, eds) (New York: Oxford University Press, 2017), 109-22, p. 111. Reichman is one of few scholars who apply humanistic affect theory to the study of law. Perhaps unsurprisingly, these authors have tended to come to affect theory by way of literary analyses of law. See also Daniel Hourigan, "Specters and Psychoanalysis in the Turn to Law and Affect," Law and Literature 31 (2019), 129-45; Greta Olson, "The Turn to Passion: Has Law and Literature Become Law and Affect?," Law and Literature, 28 (2016), 335-53. But see Illan rua Wall, "The Ordinary Affects of Law," Law, Culture and the Humanities, in press, for a novel affective take on the law as it becomes manifest in lived experience.

In speaking of "humanistic" affect theory, I distinguish this article's theoretical framing from the relatively well-developed "law and emotions" subfield of legal scholarship. The latter privileges the more scientistic disciplines in examining, descriptively as well as prescriptively, how legal doctrine and institutions are informed by assumptions about emotions. For an overview of this literature, see Susan A. Bandes and Jeremy A. Blumenthal, "Emotion and the Law," Annual Review of Law and Social Science 8 (2012), 161-81. I would also add that the distinction between affect (whose deep currents of history, signification, and materiality elude linguistic representation) and emotion (as an experience that is eminently expressable) does 
important analytical work for some affective scholars, Massumi prominent among them. I follow Reichman, however, in placing emotion front and center, even while acknowledging that empirically accessible emotions harken back to forces that elude analytical capture.

5. Investigators of affect have variously underscored its "propulsive elements" (Donovan Schaefer, Religious Affects (Durham, NC: Duke University Press, 2015), p. 23), the "prescriptions for action" embedded within it (Anna Gibbs, "Disaffected," Continuum, 16 (2002), 335-41, p. 339), and its always-forming potentialities to "move us forward and propel us into life" (Mary Zournazi, Hope: New Philosophies for Change (Annandale: Pluto Press, 2002), p. 210).

6. See Jesse Cheng, “'Mitigate from Day One': Why Effective Defense Advocates Do Not Prioritize Liberty over Life in Death Penalty Cases," Ohio State Journal of Criminal Law 14 (2016), 231-45.

7. See American Bar Association, "Guidelines," 1021-26; American Bar Association, "Supplementary Guidelines for the Mitigation Function of Defense Teams in Death Penalty Cases," Hofstra Law Review 36 (2008), 677-92. The ABA Guidelines and its mitigation supplement are a collaborative synthesis of insights from some of the most experienced advocates in the nation's capital defense bar.

8. See Gregg v. Georgia, 428 U.S. 153 (1976); Proffitt v. Florida, 428 U.S. 242 (1976).

9. In crafting their capital sentencing laws, many jurisdictions identified these factors borrowing language from Model Penal Code § 210.6(3)-(4) (Proposed Official Draft 1962). For a detailed treatment of the MPC's influence on state capital sentencing schemes and the Supreme Court's interpretations of them, see Russell Dean Covey, "Exorcizing Wechsler's Ghost: The Influence of the Model Penal Code on Death Penalty Sentencing Jurisprudence," Hastings Constitutional Law Quarterly 31 (2004), 189-268.

10. Furman v. Georgia, 408 U.S. 238 (1972).

11. A historical account of the road from Furman to Gregg is presented in Stuart Banner, The Death Penalty: An American History (Cambridge, MA: Harvard University Press, 2002), pp. 267-75.

12. Woodson v. North Carolina, 428 U.S. 280 (1976), p. 304.

13. See Susannah Sheffer, Fighting for Their Lives: Inside the Experience of Capital Defense Attorneys (Nashville: Vanderbilt University Press, 2013), for an exploration of the reflective processes that help defense advocates seek humanity in their clients.

14. Under this process, a potential juror is excluded from serving if the trial judge determines that the individual's attitudes and beliefs about capital punishment would "prevent or substantially impair the performance of [their] duties." Wainwright v. Witt, 469 U.S. 412 (1985), p. 424.

15. Dismissiveness through simplification is a stock rhetorical move: "[T] he prosecutor. . .argu[es] that many people who came from similarly troubled backgrounds have led productive lives or at least have not committed atrocious capital crimes." Welsh S. White, Litigating in the Shadow of Death: Defense Attorneys in Capital Cases (Ann Arbor: University of Michigan Press, 2006), p. 107

16. See Daniel LaChance, Executing Freedom: The Cultural Life of Capital Punishment in the United States (Chicago: University of Chicago Press, 2016), for an argument that these administrative failures portend the U.S. death penalty's undoing.

17. Jesse Cheng, "Frontloading Mitigation: The 'Legal' and the 'Human' in Death Penalty Defense," Law and Social Inquiry, 35 (2010), 39-65.

18. See, again, LaChance, Executing Freedom, particularly the chapters on the promotion of retribution as a strategy for consolidating and manifesting state power.

19. Moreover, legal advocates and academics have contended for decades that the supposedly "super" due process of capital cases is anything but. See William S. Geimer, "Death at Any Cost: A 
Critique of the Supreme Court's Recent Retreat from its Death Penalty Standards," Florida State University Law Review 12 (1985), 737-780; Ronald J. Tabak, "The Egregiously Unfair

Implementation of Capital Punishment in the United State: 'Super Due Process' or Super Lack of Due Process?", Proceedings of the American Philosophical Society 147(1) (2003), 13-23; Carol S. Steiker and Jordan M. Steiker, Courting Death: The Supreme Court and Capital

Punishment (Cambridge, MA: Belknap Press, 2016).

20. See Philip Kain, Marx and Ethics (Oxford: Clarendon Press, 1986), pp. 29-33, for an analysis of Marx's views on freedom and self-determination as the essence of humanity.

21. Woodson, p. 304.

22. Op. cit., p. 304.

23. Op. cit., p. 304.

24. Eric Freedman, "Introduction," Hofstra Law Review 31 (2003), 903-12, p. 904. Freedman is the Reporter for the ABA Guidelines.

25. Ben Anderson, "Affective Atmospheres," Emotion, Space and Society, 2 (2009), 77-81, p. 78. The internal quotes here are from Marx, who formulates a materialist concept of atmosphere that Anderson puts in productive tension with a more ethereal, phenomenological emphasis on sense experience.

26. Op. cit., p. 77. In a similar vein, Kathleen Stewart, recalling Raymond Williams, notes in her exploration of "ordinary affects" that these "do not have to await definition, classification, or rationalization before they exert palpable pressures." Kathleen Stewart, Ordinary Affects (Durham, NC: Duke University Press), p. 3.

27. The defense could force people to testify through subpoena, but experienced advocates know that the most compelling testimony is almost never coerced.

28. Russell Stetler, "Capital Cases: Mitigation Evidence in Death Penalty Cases," The Champion 23 (Jan/Feb 1999), 33-8, pp. 34-5. Stetler is the former National Mitigation Coordinator for the Federal Death Penalty Resource Counsel Project, an advisory panel of experienced capital defense practitioners.

29. James and Cross, A Practitioner's Guide, p. 25. Several contributors to this volume were also involved in the production of the ABA Guidelines.

30. Lee Norton, "Capital Cases: Mitigation Investigations," The Champion 16 (May 1992), 43-5, p. 44.

31. I experienced this reaction time and again during my own days knocking on doors. For an affective modern classic that sheds light on this phenomenon, see Lauren Berlant, Cruel

Optimism (Durham, NC: Duke University Press, 2011).

32. Here, for example, from a closing argument given by my former law professor, the capital litigator Steve Bright:

[P]eople aren't all the same. As I was thinking about this last night, I thought about the parable our Savior gave us about the sower sowing the seeds. And the seeds that fell on the rocks grew up a little bit, then the dust blew away and they died away. And some grew up in the thistles, but they were choked out by the thistles. . That's what we're talking about. We're talking about somebody whose seed was not that great to begin with and it grew up among the thorns. Goodness gracious! And more thorns kept coming up. And this little seed tried to struggle, two, three, four, six years old-through those thorns. And it was a hard time. And it was choked back over and over again. And the fact that some prosper and others don't, that's life. That's life. But that tells you something when you look at this guy and you look at his soul and you look at who he is and where he came from. 
For a discursive analysis of this particular case, see Austin Sarat, "Speaking of Death: Narratives of Violence in Capital Trials," Law and Society Review 27 (1993), 19-58.

33. Molly Treadway Johnson and Laurel L. Hooper, Resource Guide for Managing Capital Cases, Volume I: Federal Death Penalty Trials (Washington, DC: Federal Judicial Center, 2004), p. 55.

34. "Counsel at every stage of the case have an obligation to take all steps. . to achieve an agreedupon disposition." American Bar Association, "Guidelines," p. 1035.

35. Op. cit., p. 1016.

36. Such challenges, which may occur at different points in the proceedings and justify ancillary investigations in their own right, include competency to stand trial, ability to comprehend Miranda warnings, waiver of right to counsel and other constitutional rights, and competency to enter a plea. David Freedman, "Mental Illness and Behavior" (2001, practitioner training notes on file with author), pp. 1-2. These claims characteristically turn on corroboration of the defendant's impairments through the mitigation investigation's life history evidence. As prosecution agencies reallocate resources and manpower to the next big murder in the headlines, the defense does not actually have to win these pretrial proceedings to consume the prosecution's energies. But successful challenges can certainly convince the state to reassess whether a case remains logistically deathworthy.

37. Stewart, Ordinary Affects, p. 3.

38. Arlene Andrews, "Interview Basics-for Mitigation" (2006, practitioner training notes on file with author), p. 1. See also Scharlette Holdman, The Nature and Role of Mitigating Evidence in Capital Cases (undated memo on file with author), p. 27 (advocates must "develop trusting relationships with untrusting, confused, mentally ill offenders. . They work with polarized, enmeshed, self-defeating family systems to gain their families' cooperation and trust. . ."); Norton, "Mitigation Investigations," p. 44 ("[I]t is unlikely that the client will have immediate trust for members of the defense team. In many instances, the client's disabilities have been exploited and $\mathrm{s} /$ he has been deceived and manipulated by individuals $\mathrm{s} / \mathrm{he}$ trusted to help him/her.").

39. Andrews, "Interview Basics," p. 4.

40. Op. cit., p. 4.

41. When engaging with "individuals who lie," for instance, the advocate must recognize that "lying is different than repression or denial for emotional reasons. . . Let them talk-use reflective listening. Observe how they lie." Op. cit., p. 6.

42. According to one well-respected attorney-investigator, "basic ground rules" for visits with witnesses include "no phone interviews" and "no calling ahead of time." Danalynn Recer, "Learning Your Client's Story" (undated practitioner training PowerPoint slides on file with author), p. 56. See also James and Cross, A Practitioner's Guide, p. 24 ("Full disclosure comes only in person with great patience, using multiple one-on-one face-to-face interviews, no matter how skilled the interviewer.").

43. Hence, the need for "[m]ultiple interviews. . conducted with the offender, family members, peers, and others who have known the offender over time. ." Holdman, The Nature and Role, p. 19.

44. Stetler, "Mitigation Evidence," p. 38.

45. Millard Farmer, the recently passed capital lawyer, has said, "Every day you keep your man alive is a victory." John Temple, The Last Lawyer: The Right to Save Death Row Inmates (Jackson, MI: University Press of Mississippi, 2009), p. 99.

46. Williams v. Taylor, 529 U.S. 362 (2000), Wiggins v. Smith, 539 U.S. 510 (2003), and Rompilla v. Beard, 545 U.S. 374 (2005) explicitly addressed requirements for sentencing investigations, 
legitimizing minimum standards that the defense now routinely invokes to request time and resources for continued investigation. Skipper v. South Carolina, 476 U.S. 1 (1986) made postincarceration evidence of the client's ability to thrive under structured conditions relevant to mitigation, thereby calling for comparison with pre-incarceration life conditions marred by instability. In holding that the defense cannot be denied expert services when mental health is significantly at issue, Ake v. Oklahoma, 470 U.S. 68 (1986) buttressed the need for the comprehensive life history investigation that any competent mental health expert would require as part of their evaluation. And Atkins v. Virginia, 536 U.S. 304 (2002) established the intellectually disabled as categorically exempt from the death penalty, providing the defense grounds to investigate the client's deficiencies across several functional domains over the life course.

47. My thanks to Danalynn Recer for this last one.

48. Judith Butler, Notes Toward a Performative Theory of Assembly (Cambridge, MA: Harvard University Press, 2015), p. 11.

49. Judith Butler, Undoing Gender (London: Routledge, 2004), p. 39.

50. Butler, Notes, p. 36. 